Scientific Journal Warsaw University of Life Sciences - SGGW

Problems of World Agriculture volume 18 (XXXIII), number 2, 2018: 95-104

DOI: 10.22630/PRS.2018.18.2.37

Dorota Janiszewska $^{1}$, Luiza Ossowska ${ }^{2}$

Koszalin University of Technology

\title{
Diversification of European Union Member States Due to the Production of Renewable Energy from Agriculture and Forestry
}

\begin{abstract}
The main objective of this article is to discuss the diversity of European Union countries in terms of their production of renewable energy from agriculture and forestry. The analysis includes 28 EU countries. Figures come from 2013-2015. Diversification of European Union members was conducted using cluster analysis. The following diagnostic features were used for the analysis: production of renewable energy from agriculture, share of agriculture in production of renewable energy, change in the production of renewable energy from agriculture in 2013-2015, production of renewable energy from forestry, share of forestry in production of renewable energy, change in the production of renewable energy from forestry in 2013-2015. As a result of the cluster analysis examined regions were divided into five groups.
\end{abstract}

Key words: agricultural biomass, forest biomass, European Union countries, production of renewable energy

JEL Classification: Q22, Q23

\section{Introduction}

Economic development contributes to an increase of energy needs. In order to reduce the consumption of primary energy sources such as coal, oil and gas, EU countries promote the use of energy from renewable sources (Jędrejek, Jarosz, 2017). The result of these actions is the Directive 2009/28/EC (Dz. U. UE L 09.140.16.2009) adopted in April 23, 2009 on the promotion of the use of energy from renewable sources according to which, by 2020 the EU countries are expected to increase the share of renewable energy in gross final consumption to $20 \%$. Development of renewable energy supports political targets related to cutting down $\mathrm{CO}_{2}$ emissions, to help reduce climate change (Saerbeck, Bianchi, 2008). Presently energy from biomass dominates the production of renewable energy in EU countries. In 2015, $63.5 \%$ of renewable energy in the EU was produced from this source (EUROSTAT, 2017). The biomass structure is dominated by forest an agricultural biomass (European Commission, 2017).

The term biomass is defined in both Polish and EU legal regulations. According to the Directive 2009/28/EC (Directive 2009/28/EC art. 2e) of the European Parliament and of the Council, and the Act of August 26, 2006 on biocomponents and liquid biofuels (2006, art. 2), biomass means the biodegradable fraction of products, waste and residues from agricultural biological origins (including vegetal and animal substances), forestry and related industries including fisheries and aquaculture, as well as the biodegradable fraction of industrial and municipal waste.

${ }^{1} \mathrm{PhD}$, Department of Economic and Regional Policy, 6E Kwiatkowskiego Str., 75-343 Koszalin, e-mail: dorota.janiszewska@tu.koszalin.pl

${ }^{2} \mathrm{PhD}$, Department of Economic and Regional Policy, 6E. Kwiatkowskiego Str., 75-343 Koszalin, e-mail: luiza.ossowska@tu.koszalin.pl 
Existing literature on the subject lists many classifications of biomass. But most often biomass is classified by direction of origin - agricultural biomass, forestry biomass and biomass from wastes (Kołodziej, 2012; Godlewska-Majkowska, Zarębski, 2012; Odnawialne..., 2013); the degree of processing - primary energy raw materials, secondary energy raw materials and energy carriers (Korycińska, 2009; Grzybek, 2008) and state of aggregation - solid, liquid and gas (Kołodziej, 2012; Berenet-Kowalska, Kacprowska, Moskal, Jurgaś, Kacperczyk, 2014).

Agricultural biomass are: waste and plant and animal production by-products, waste and by-products from processing of plant and animal raw materials and annual (oilseeds, root crops and legumes) and perennial plants (willow, miscanthus grass, virginia mallow). Forestry biomass are: waste wood, compressed wood, forestry waste and waste from the wood and paper industry (Kołodziej, 2012; Godlewska-Majkowska, Zarębski, 2012; Odnawialne..., 2013).

The use of agricultural and forestry biomass for energy purposes brings many benefits: the reduction of pollutant emissions in relation to the combustion of primary fuels; utilization of production waste from forestry and agricultural industry; the possibility of creating various forms of energy from heat to electric energy to fuel for cars; stability of energy from biomass in relation to the unpredictable solar or wind energy; availability of resources around the world, ensuring delivery from the same country, the possibility of obtaining income in overproduction of resources, creation of new jobs, reduction of $\mathrm{CO}_{2}$ emissions and decentralization of energy production - energy security (Ociepa-Kubicka, 2015). Despite so many advantages, it should be noted that the resources of agricultural and forest biomass are strictly defined in the scope of the annual use for energy purposes. The limited use of agricultural and forestry biomass is due to the use of these resources for food and production needs (Wójcicki, 2012).

\section{The aim and research method}

The main objective of this article is to discuss the diversity of European Union countries in their production of renewable energy from agriculture and forestry. The analysis includes 28 EU countries. Figures come from 2013-2015. The data comes from the EUROSTAT publication.

Diversification of European Union members was conducted using the cluster analysis. The research used the so-called Euclidean Distance, understood as the function of similarity, using the formula (Parysek, Wojtasiewicz, 1979):

$$
d_{i k}=\sqrt{\sum_{j=1}^{m}\left(x_{i j}-x_{k j}\right)^{2}},
$$

where: $d_{i k}$ - distance between $i$-th and $k$-th object (for $i=k=1,2, \ldots, n$ ), $x_{i j}$ - value of $j$-th variable for $\mathrm{i}$-th object (for $\mathrm{j}=1,2, \ldots, \mathrm{m}), \mathrm{x}_{\mathrm{kj}}$ - values $\mathrm{j}$-th variable for $\mathrm{k}$-th object. Standardized variables were used for calculations. During the research, J.H. Ward method was applied. It involves connecting those clusters, that as a whole provide a minimum sum 
of squared distances from the centroid of a new cluster, which they form (Parysek, Wojtasiewicz, 1979).

The analysis was conducted based on six selected indicators:

- production of renewable energy from agriculture (toe/1000 inhab.),

- share of agriculture in production of renewable energy (\%),

- change in the production of renewable energy from agriculture in 2013-2015 (\%),

- production of renewable energy from forestry (toe/1000 inhab.),

- share of forestry in production of renewable energy (\%),

- change in the production of renewable energy from forestry in 2013-2015 (\%)

Selection of indicators was conducted based on the substantive and statistical criteria, and the availability of complete data was also taken into account.

\section{Results}

Figure 1 presents data on renewable energy production from agriculture in EU countries in 2015. Average level of production per one country is 37 toe/1000 inhab. Index values range from 0 (Estonia) to 127 (Germany). The highest values indicator of renewable energy production from agricultural biomass were characterized by Germany and The Netherlands. Together, these two countries produced 235 toe/1000 inhab. Renewable energy from agriculture accounts for almost $23 \%$ of the EU production level. Quite a high indicator of renewable energy production characterizes Finland, Austria, Belgium, the Czech Republic and Latvia. Total renewable energy production from agriculture in these countries is almost 387 toe/1000 inhab. (above $37 \%$ of EU production in 2015). In most countries, the production of renewable energy from agriculture has not reached the average level. The least favourable situation in this respect was registered in Estonia, Malta, Bulgaria, Ireland and Romania. In these countries, only 21 toe/1000 inhabs of renewable energy from agriculture was produced, which gives 4 toe/1000 inhab per country.

Figure 1 also presents the change in production of renewable energy (in toe) from agriculture in 2013-2015 (in \%). Taking into account the change in production of renewable energy from agriculture between 2013 and 2015 there was an increase in most countries. In The United Kingdom, Denmark, Finland, Malta, Latvia and Slovakia the change was above $50 \%$. There were no changes in Belgium and Estonia. In contrast there was a decrease in the production of renewable energy from agriculture in seven countries during the analyzed period, especially in Greece (37\%) and Romania (28\%).

Figure 2 presents the share of agriculture in production of renewable energy in EU member states in 2015. Average share of agriculture in production of renewable energy per country in 2015 was almost 10\%. Index values range from 0 (Estonia) to $38 \%$ (Netherlands). The highest share of agriculture in production of renewable energy was characterized by The Netherlands (38\%), Belgium (28\%) and Germany (27\%). In these countries there is also a high indicator of renewable energy production in toe/1000 inhab. The next countries are Slovakia and the Czech Republic with almost $20 \%$ share of agriculture in renewable energy production. Most countries achieved an average share of agriculture in renewable energy. In 11 countries the share of agriculture in renewable energy production did not exceed the average value. The lowest values were in Estonia $(0 \%)$, and Sweden (less than $1 \%)$. 


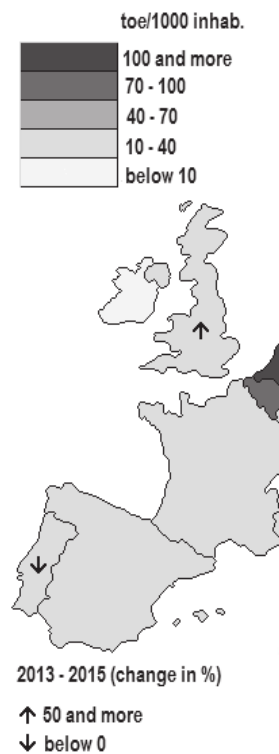

$\downarrow$ below 0

Fig. 1. Production of renewable energy from agriculture in EU member states in 2015

Source: own research based on: European Commission (2017). Cap context indicators 2014 2020, p. 190.

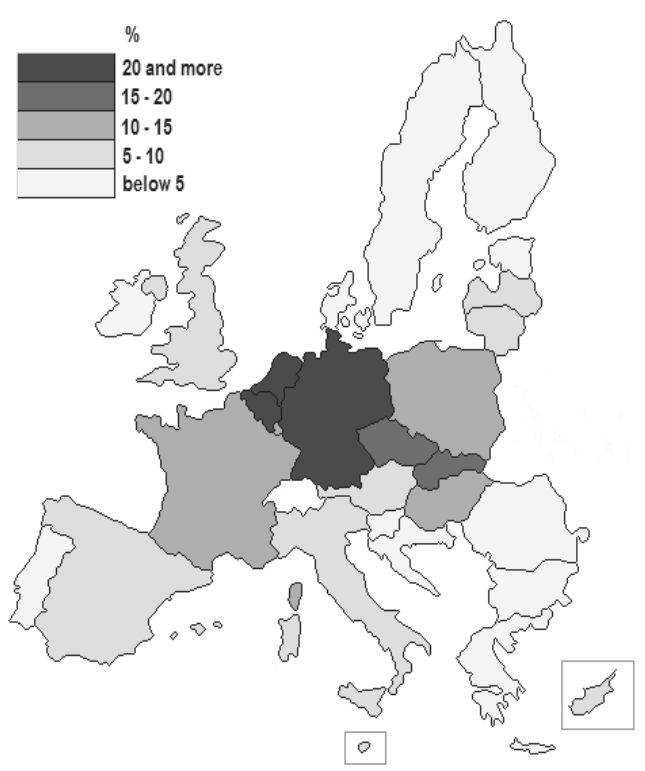

Fig. 2. Share of agriculture in production of renewable energy in EU member states in 2015

Source: own research based on: European Commission (2017). Cap context indicators 20142020, p. 190.

Figure 3 contains information on renewable energy production from forestry in EU countries in 2015. The average level of production per one country is 309 toe/1000 inhab. Index values range from 0 (Malta) to 1444 (Finland). The highest level of renewable energy production is characterized by countries in the north part of Europe: Finland, Latvia, Sweden and Estonia. In 2015 the total production of renewable energy from forestry in these countries amounted to 4,3 thous. toe/1000 inhab., which is half of EU total production. Also, quite high indicators of production are shown by Austria, Lithuania and Croatia. In those countries in the analyzed year, 1,3 thous. toe/1000 inhab. of renewable energy from forestry were made, which is $15 \%$ of EU production. In most countries EU production did not reach the average level. The lowest indicator values characterized Malta (no production) and Cyprus (less than 8 toe/1000 inhab.).

In 2013-2015, in most countries, the production of renewable energy from forestry increased, especially in The United Kingdom and Cyprus. It should be noted that these countries are characterized by low values of production indicators. In 11 countries, a decrease in the production of renewable energy from forestry has been observed. In most countries, the decrease is small, the most significant of which was noted in Belgium.

Figure 4 contains information on the share of forestry in renewable energy production in EU countries in 2015. The average indicator value per one EU country is $50 \%$. Index values range from 0 (Malta) to $94 \%$ (Estonia). The highest share of forestry in renewable energy production characterizes Estonia, Latvia and Lithuania, where values of indicators exceed $80 \%$. Next are Hungary, Finland, Poland, the Czech Republic and Croatia. In these 
countries the share of forestry in renewable energy production is above $60 \%$. In 15 countries the share of forestry in renewable energy production is below $50 \%$; that is below the average level. The lowest values in production and share of renewable energy from forestry characterizes Malta ( $0 \%$ no production) and Cyprus (less than 6\%).

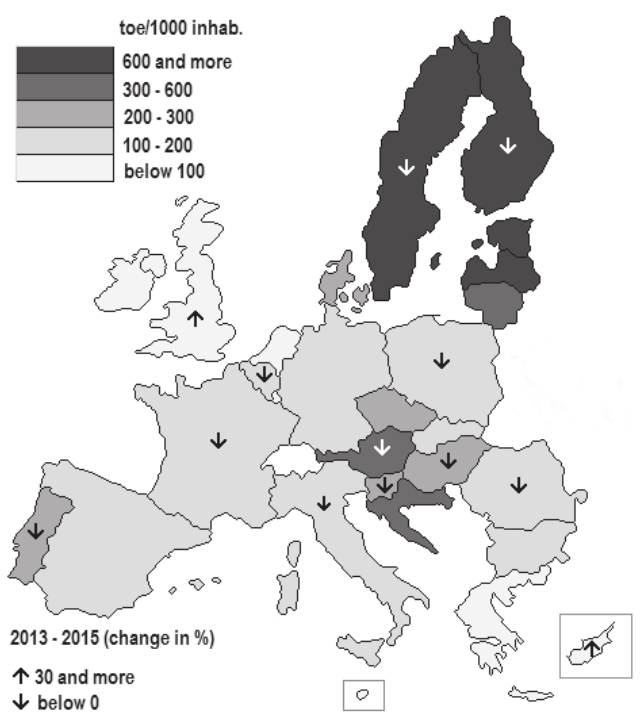

Fig. 3. Production of renewable energy from forestry in EU member states in 2015

Source: own research based on: European Commission (2017). Cap context indicators 20142020, p. 191.

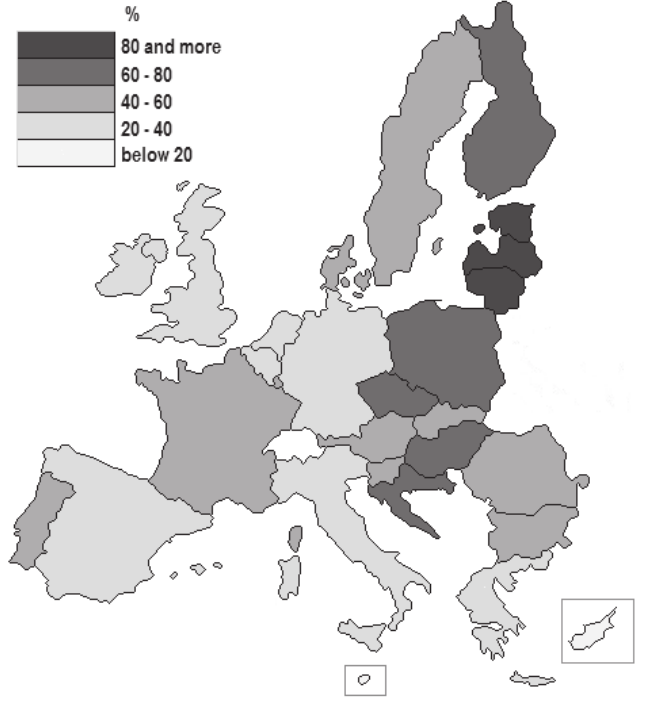

Fig. 4. Share of forestry in production of renewable energy in EU member states in 2015

Source: own research based on: European Commission (2017). Cap context indicators 20142020, p. 191

Comparing the discussed indicators, the European Union countries were divided into five different groups (Figure 5, Table 1). Group I included three countries: Belgium, The Netherlands and Germany. This group of countries differs from the others with the highest indicators of production and the highest share of agriculture in renewable energy production. Values of indicators exceeds 100 toe/1000 inhab. and it is twice as high as in Group III (the second in this respect). The share of agriculture in renewable energy production exceeds $30 \%$ in this group, which is two and a half times higher than in the next group in this respect. The level of changes in the renewable energy production in this group of countries is slightly lower than the average for the EU. At the same time, the indicators regarding the importance of forestry in the renewable energy production are characterized by lower than average values for the $\mathrm{EU}$ in this group.

Group II was created by six countries: the Czech Republic, Denmark, Lithuania, Luxemburg, Slovakia and the United Kingdom. These countries are characterized by the greatest change among all groups of countries in renewable energy production from agriculture and forestry. In addition, this group of countries is characterized by the average volume of renewable energy production from agriculture, with a relatively high share of agriculture in the renewable energy production. Their share of forestry in renewable energy 
production has been on an average level, while the volume of renewable energy production from forestry per country in this group did not exceed the EU average.

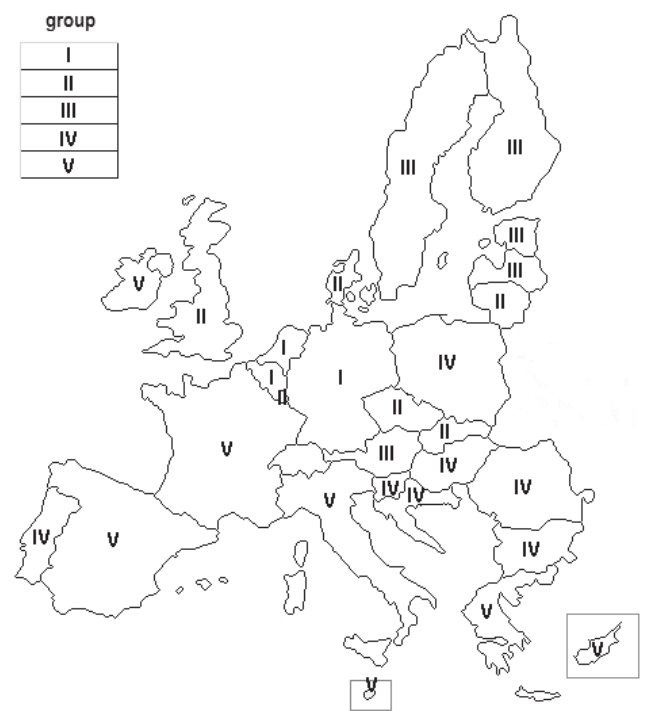

Fig. 5. Diversification of EU member states due to the production of renewable energy from agriculture and forestry - typological groups

Source: Authors' own research.

Group III included five countries: Estonia, Latvia, Austria, Finland and Sweden. Countries within this group are characterized by a great deal of importance of forestry in renewable energy production. The value of production indicator per country in this group reaches almost1 thous. toe/1000 inhab. and is four times higher than in Group III (next in terms of production volume), while the share of forestry in the renewable energy production in this group exceeds $70 \%$ per each country. It should be noted, that in the scope of the importance of agriculture in renewable energy production within Group III countries, there was quite a high value of production indicator, with a very small share of agriculture in the renewable energy production. The dynamics of change turned out to be greater in the case of renewable energy production from agriculture than from forestry. Positive values were recorded in both cases.

Group IV included seven countries: Bulgaria, Croatia, Hungary, Poland, Portugal, Romania and Slovenia. A characteristic feature of this group are negative indicators of change in the production of renewable energy from agriculture and forestry recorded in most countries. In addition, this group is characterized by the lowest rate of renewable energy production from agriculture, which does not exceed 16 toe/1000 inhab per country. The share of agriculture in the production of renewable energy in this group was two times lower than the EU average. The importance of forestry in renewable energy production of these countries is greater. Both the volume of production per country and the share of forestry in the production of renewable energy are higher than in the case of Groups I, II and V, smaller only in comparison with Group III. 
Table 1. Diversification of EU member states due to the production of renewable energy from agriculture and forestry - indicators by typological groups

\begin{tabular}{|c|c|c|c|c|c|c|}
\hline Specification & Group & $\begin{array}{l}\text { Group } \\
\text { II }\end{array}$ & $\begin{array}{l}\text { Group } \\
\text { III }\end{array}$ & $\begin{array}{l}\text { Group } \\
\text { IV }\end{array}$ & $\begin{array}{l}\text { Group } \\
\text { V }\end{array}$ & Total \\
\hline $\begin{array}{l}\text { Production of renewable energy from agriculture } \\
\text { (toe/1000 inhab.) }\end{array}$ & 103,0 & 39,5 & 51,1 & 15,8 & 18,3 & 37,2 \\
\hline $\begin{array}{l}\text { Share of agriculture in production of renewable } \\
\text { energy }(\%)\end{array}$ & 30,8 & 11,8 & 3,8 & 4,7 & 7,6 & 9,6 \\
\hline $\begin{array}{l}\text { Change in production of renewable energy from } \\
\text { agriculture in } 2013-2015(\%)\end{array}$ & 13,5 & 48,1 & 34,7 & $-5,8$ & 7,9 & 18,5 \\
\hline $\begin{array}{l}\text { Production of renewable energy from forestry } \\
\text { (toe/1000 inhab.) }\end{array}$ & 111,2 & 215,8 & 966,9 & 236,8 & 74,1 & 308,5 \\
\hline $\begin{array}{l}\text { Share of forestry in production of renewable } \\
\text { energy }(\%)\end{array}$ & 33,0 & 55,5 & 70,8 & 63,3 & 24,2 & 50,0 \\
\hline $\begin{array}{l}\text { Change in the production of renewable energy } \\
\text { from forestry in } 2013-2015(\%)\end{array}$ & 2,8 & 16,9 & 3,9 & $-2,4$ & 6,5 & 5,7 \\
\hline
\end{tabular}

Source: Authors' own calculations based on research of the European Commission (2017). Cap context indicators 2014-2020, p. 190-191.

Group V included seven countries: Ireland, Greece, Spain, France, Italy, Cyprus and Malta. These countries are characterized by a relatively small production of renewable energy from agricultural biomass, with a small share of agriculture in the production of renewable energy. In addition, the lowest share of forestry in the production of renewable energy was recorded among all the examined groups, with the lowest production of this energy from forestry. These are countries where (apart from France) the share of biomass in the production of renewable energy does not exceed $50 \%$, and other sources are of great importance in the production structure of renewable energy.

\section{Discussion}

Renewable energy production and consumption has a positive impact not only on the environment but also on economics - for example on gross domestic product (Aceleanu, Serban, Pociovaisteanu, Dimian, 2017; Akar, 2016; Cetin, 2016). The European Union leads in renewable energetics and biomass is the most popular renewable energy resource (European Commission 2015). However the production and consumption of renewable energy is diversified at the national level (Fischer, 2014; Ringel, Knodt, 2018).

Diversity is caused, among others things, by determinants in individual countries. Referring to the presented research results, Group I - characterized by the largest share of agriculture in the production of renewable energy - includes countries with a high level of agriculture's functional development (see: Janiszewska, Ossowska, 2016). Hence the large possibilities of obtaining biomass from this source. In Belgium and The Netherlands, the highest potential of agricultural biomass can be obtained from animal production and in Germany from crop production as well (see: Janiszewska, Ossowska, 2015).

Group III - characterized by the largest share of forestry in the production of renewable energy - includes countries with a well-developed forest function, associated 
with significant forest cover (see: Ossowska, Janiszewska, 2016). Forest management allows biomass to be obtained from this source.

In most countries of Group $\mathrm{V}$, sources other than biomass are also important in the production of renewable energy. Among the southern countries it is solar energy (Malta, Cyprus, Greece and Spain). Coastal countries quite commonly use wind energy (Spain, Cyprus, Greece). Also a large share of energy comes from: hydropower (France, Greece, Italy and Spain) and geothermal energy (Italy) (EUROSTAT, 2017). Therefore, the natural conditions of these countries influence the structure of using renewable energy sources.

Other highlighted groups include countries with a fairly high level of change in the production of renewable energy from agricultural and forest biomass. Changes in renewable energy are not only dependent on EU policy, but also on the situation at the national level. Negative changes - characterizing Group IV - in most cases are not a result of changes in the size of agricultural and forestry production (see: EUROSTAT, 2016). They are related to, for example, energy policy conducted at the national level, especially in Central and Eastern Europe, where this policy is based on the national energy mix and renewable energy sources are not seen as important (other than as a part of EU policy) (Fischer, 2014; Ringel, Knodt, 2018). Positive changes - characteristic of Group II - are related to common energy policies, and the assumption that the share of renewable sources in energy production should be related to the growth of energy consumption. In the EU a number of support mechanisms have been introduced, such as: investment aid, tax exemptions, tax refunds and subsidies for the price paid to the producer (Luty, Zioło, 2016).

Considering the EU's common energy policy, we should expect an increase in pressure for the management of biomass from waste, including agricultural and forest biomass. This increase will be dictated by both the necessity of waste management and the need to achieve further targets in the share of renewable energy on total energy consumption (Pudełko, 2013; European Commission, 2014).

\section{Conclusions}

Biomass, in particular agricultural and forestry biomass, is the most widely used source of renewable energy in Europe. According to the main objective, the article discusses the diversity of EU countries due to the production of renewable energy from agriculture and forestry. As the result of the analysis, EU countries were divided into five groups with different characteristics in the field of renewable energy from agriculture and forestry. Group I is characterized by high importance of agriculture in the production of renewable energy. Group II is characterized by a fairly high level of positive changes in energy production from agriculture and forestry. Group III is characterized by high importance of forestry in the production of renewable energy. Group IV is characterized by a fairly high level of negative changes in the production of renewable energy from agriculture and forestry. In Group V, sources other than biomass play a large role in the production of renewable energy.

The production of renewable energy from agriculture and forestry is affected not only by natural conditions and EU energy policy, but also by the situation in individual countries. In view of the energy policy pursued by the European Union, a further increase in the use of biomass, including agricultural and forest biomass, can be expected in the future. 


\section{References}

Aceleanu, M.I. Serban, A.C., Pociovalisteanu, D.M., Dimian, G.C. (2017). Renewable energy: A way for a sustainable development in Romania. Energy Sources Part B. 12(11), 958-963.

Akar, B.G. (2016). The determinants of renewable energy consumption: An empirical analysis for The Balkans. European Scientific Journal, 12(11), 594-607.

Berent-Kowalska, G., Kacprowska, J., Moskal, I., Jurgaś, A., Kacperczyk, G. (2014). Energia ze źródeł odnawialnych w 2013 roku (Energy from renewable sources in 2013). Statistical information and studies, Central Statistical Office, Warszawa.

Cetin, M.A. (2016). Renewable energy consumptions - economic growth nexus in E-7 countries. Energy Sources Part B, 11(12), 1180-1185.

Directive 2009/28/EC of the European Parliament and of the Council of 23 April 2009 on the promotion of the use of energy from renewable sources and amending and subsequently repealing Directives 2001/77/EC and 2003/30/EC, art. 2e, 11

European Commission (2015). The European Union leading in renewable. Re-Energising the Future COP21. Brussels, 1-28.

European Commission (2014). Communication From The Commission To The European Parliament, The Council, The European Economic And Social Committee And The Committee Of The Regions. A policy framework for climate and energy in the period from 2020 to 2030 (COM/2014/015 final). Brussels.

European Commission (2017). Cap context indicators 2014-2020, Agriculture and Rural Development, $190-191$.

EUROSTAT (2017). Energy, transport and environment indicators. Statistical Books, 37.

EUROSTAT (2016). Agriculture, forestry and fishery statistics. Statistical Books, 88-121, 166-186.

Fischer S. (2014). The EU's new energy and climate: policy framework for 2030. SWP Comments, 55, 1-8.

Godlewska-Majkowska, H., Zarębski, P. (2012). Odnawialne źródła energii jako czynnik zmian strukturalnych w polskim rolnictwie (Renewable energy sources as a factor of structural changes in Polish agriculture). In: Zielona energia w Polsce (Green energy in Poland), D. Niedziółka (ed.), Wyd. CeDeWu, Warszawa.

Grzybek, A. (2008). Zapotrzebowanie na biomasę i strategie energetycznego jej wykorzystania (Demand for biomass and energy use strategies). In: Uprawa roślin energetycznych a wykorzystanie rolniczej przestrzen produkcyjnej w Polsce (Cultivation of energy crops and use of agricultural production space in Poland), Studia i Raporty IUNG - PIB, Zeszyt 11, Puławy, 9.

Janiszewska, D., Ossowska, L. (2016). Zróżnicowanie funkcji rolniczej w krajach Unii Europejskiej na podstawie wybranych cech (Diversification of agricultural function in countries of the European Union based on the selected indicators). Zeszyty Naukowe SGGW, Problemy Rolnictwa Światowego, 16(2), 134-144.

Janiszewska, D., Ossowska, L. (2015). Zróżnicowanie uwarunkowań rolnictwa dla produkcji energii odnawialnej z biomasy w krajach Unii Europejskiej (Diversification of agricultural determinants for renewable energy production using agricultural biomass in European Union countries). Zeszyty Naukowe SGGW, Problemy Rolnictwa Światowego, 15(2), 75-84.

Jędrejek, A., Jarosz, Z. (2017). Potencjał biomasy rolniczej na cele energetyczne w województwie lubelskim (Potential of agricultural biomass for energy purposes in the lubelskie voivodeship). Roczniki Naukowe Stowarzyszenia Ekonomistów Rolnictwa i Agrobiznesu, 19(3), 98-103.

Kołodziej, B. (2012). Energia biomasy (Biomass energy). In: Odnawialne źródła energii. Rolnicze surowce energetyczne (Renewable energy sources. Agricultural energy resources), B. Kołodziej, M. Matyka, (ed.), PWRiL, Poznań, 171-172.

Korycińska, A. (2009). Stan rozwoju sektora bioenergii (The state of development of the bioenergy sector). In: Odnawialne źródła energii nowym wyzwaniem dla obszarów wiejskich w Polsce (Renewable energy sources a new challenge for rural areas in Poland), B. Kucharska (ed.), Fundacja Programów Pomocy dla Rolnictwa FAPA, Opole.

Luty, L., Zioło, M. (2016). Zróżnicowanie odnawialnych źródeł energii w krajach grupy wyszehradzkiej (Diversification of renewable energy sources in the Visegrad Group countries). Metody Ilościowe w Badaniach Ekonomicznych, 17(2), 75-85.

Ociepa-Kubicka, A. (2015). Wykorzystanie biomasy w przedsiębiorstwach energetycznych (The use of biomass in energy enterprises). Proceedings of ECOpole, 9(1), 279-286.

Odnawialne źródła energii (Renewable energy sources), Gołębiowska U. (ed.), (2013). EKSPERT - SITR, Koszalin.

Ossowska, L. Janiszewska, D. (2016). Zróżnicowanie funkcji lasów w krajach Unii Europejskiej (The diversification of forestry function in European Union Countries). Zeszyty Naukowe SGGW, Problemy Rolnictwa Światowego, 16(3), 292-300. 


\section{4}

Parysek, J., Wojtasiewicz, L. (1979). Metody analizy regionalnej i metody planowania regionalnego (Methods of regional analysis and regional planning methods). PWN, Warszawa.

Pudełko, R. (2013). Ocena potencjałów biomasy ubocznej i odpadowej w UE-27 i Szwajcarii oraz ich regionalizacja (Assessment of biomass and waste biomass potentials in the EU-27 and Switzerland and their regionalization). Monografie i Rozprawy Naukowe, nr 39, IUNG-PIB, Puławy.

Ringel, M., Knodt, M. (2018). The governance of the European Energy Union: efficiency, effectiveness and acceptance of the Winter Package 2016. Energy Policy, 112, 209-220.

Saerbeck, R., Bianchi, M. (2008). Evaluation of renewable energy. Projects in Europe. Synthesis Report.

Ustawa z dnia 25 sierpnia 2006 r. o biokomponentach i biopaliwach ciekłych (The Act of 25 August 2006 on biocomponents and liquid biofuels) (Dz. U. $2006 \mathrm{Nr} 169$ poz. 1199).

Wójcicki, Z. (2012). Znaczenie biomasy i innych odnawialnych zasobów energii (The importance of biomass and other renewable energy resources). Problemy Inżynierii Rolniczej, 20(4), 5-13.

\section{For citation:}

Janiszewska D, Ossowska L. (2018). Diversification of European Union Member States Due to the Production of Renewable Energy from Agriculture and Forestry. Problems of World Agriculture, 18(2), 95-104; DOI: 10.22630/PRS.2018.18.2.37 